\title{
ENTRE LA MEMORIA Y LA HISTORIA: LOS CENTENARIOS DE LA ABOLICIÓN DE LA INQUISICIÓN ESPAÑOLA EN LA ENCRUCIJADA DE LA MONARQUÍA Y LA REPÚBLICA*
}

\author{
POR \\ JIMENA TCHERBBIS TESTA ${ }^{1}$ \\ Universidad Torcuato di Tella - Consejo Nacional de Investigaciones Científicas y Técnicas
}

\begin{abstract}
RESUMEN
Dos fechas resultan imprescindibles para calibrar la memoria sobre la Inquisición española en el centenario de su abolición: 1910-1912 y 1934, la primera referida a su inicial supresión tras la promulgación de la Constitución de Cádiz y la segunda a su abolición definitiva durante la Regencia de María Cristina de Borbón. Se trata de dos momentos centenarios distintos, uno signado por la Restauración y otro por la Segunda República. El artículo analiza los centenarios desde una perspectiva comparada para dar cuenta de los cambios y continuidades en las culturas políticas y en los modos de concebir la relación entre nacionalismo y catolicismo. Se demuestra que la conmemoración de la abolición de la Inquisición fue objeto de intenso debate en la prensa y que las distintas memorias en pugna contribuyeron a una reflexión más amplia sobre las condiciones de la creencia y la (im)posibilidad de imaginar un nuevo orden político.
\end{abstract}

PALABRAS CLAVE: Inquisición; memoria; nacionalismo; restauración; república.

\section{BETWEEN MEMORY AND HISTORY: THE CENTENARIANS OF THE ABOLITION OF THE SPANISH INQUISITION AT THE CROSSROADS OF THE MONARCHY AND THE REPUBLIC}

\begin{abstract}
Two dates are essential to calibrate the memory of the Spanish Inquisition in the centenary of its abolition: 1910-1912 and 1934, the first referred to its initial suppression after the promulgation of the Constitution of Cádiz and the second to its final abolition during the Regency of María Cristina de Borbón. These are two different centenary moments, one during the Restoration and the other during the Second Republic. The paper analyzes the centenarians from a comparative perspective to account for changes and continuities in the political cultures and in their ways of conceiving the relation between nationalism and Catholicism. We aim to demonstrate that the commemoration of the abolition of the Inquisition was subject of intense debate in the press and that the various memories in conflict contributed to a broader reflection on the conditions of belief and the (im)possibility of imagining a new political order.
\end{abstract}

KEY WORDS: Inquisition; memory; nationalism; restoration; republic.

Cómo CITAR ESTE ARTículo / CitATION: Tcherbbis Testa, Jimena. 2021. «Entre la memoria y la historia: los centenarios de la abolición de la Inquisición española en la encrucijada de la monarquía y la república». Hispania Sacra LXXIII, 147: 235-248. https:// doi.org/10.3989/hs.2021.020

Recibido/Received 18-12-2019

Aceptado/Accepted $\quad 09-06-2020$

El presente trabajo se realizó en el marco de la investigación doctoral titulada «El pensamiento liberal y la opinión pública. El debate a propósito de la Inquisición española en perspectiva comparada: Cádiz, Buenos Aires y Lima (1808-1864)» defendida en el año 2019 en la Universidad Torcuato di Tella y financiada por el Consejo Nacional de Investigaciones Científicas y Técnicas de la Argentina (tesis inédita).

1 jime-tt@hotmail.com / ORCID iD: https://orcid.org/0000-0002-2419-2655 


\section{INTRODUCCIÓN}

Las sociedades humanas se han construido y, podríamos también decir, se han gobernado a través de las creencias. ${ }^{2}$ Entre aquellas creencias, las religiosas han ocupado un lugar significativo en la historia de Occidente. En efecto, la construcción de un lazo social no asentado en la unanimidad religiosa constituyó uno de los principales desafíos de la historia moderna y contemporánea. En el caso de las sociedades hispano-americanas pertenecientes a la Monarquía Católica la defensa de la libertad de conciencia fue clave en la edificación de un orden liberal contrario a los fundamentos unanimistas del Antiguo Régimen. La reivindicación de las libertades individuales se realizó en el marco de una intensa disputa anticlerical que convirtió a la Inquisición española en símbolo de intransigencia político-religiosa. La cuestión inquisitorial, en la medida en que remitía a la compleja relación entre religión y política, específicamente entre Iglesia y Monarquía, se transformó en un asunto clave de la controversia anticlerical del período contemporáneo. Si por un lado, durante los primeros años del siglo XIX, la crítica liberal al Santo Oficio se orientaba a legitimar su abolición procurando evitar que el Tribunal de la Fe supusiera una amenaza para las libertades civiles y políticas de los católicos españoles, durante las décadas venideras y entrado el siglo XX, la Inquisición se convirtió en un símbolo de la alianza entre el Estado y la Iglesia que el anticlericalismo, especialmente en su inflexión republicana y demócrata, cuestionaba reconociendo a la religión como un derecho del individuo.

Por cierto, la Inquisición española gravitó sobre el orbe hispano durante más de tres siglos. Fundada en el año 1478, merced a la Bula papal de Sixto IV durante el reinado de los Reyes Católicos, fue abolida definitivamente en el año 1834 por un decreto de la regencia de María Cristina de Borbón. Pero no solo fue extensa su permanencia en el tiempo, sino también su jurisdicción territorial. El Santo Oficio español tenía jurisdicción en la Península y en América. Desde el año 1569 , durante el reinado de Felipe II, se decidió instalar tribunales, dependientes del Consejo General de la Suprema Inquisición, en el nuevo continente. ${ }^{3}$ Su permanencia a lo largo del tiempo y en espacios tan diversos se debió, en gran parte, a su capacidad de identificar nuevas amenazas hacia la ortodoxia: desde la herejía judaizante y el peligro morisco a la amenaza luterana, que a la luz del Concilio de Trento (1545-1563) obligaba a vigilar los comportamientos de los mismos cristianos viejos y, finalmente, desde el siglo XVIII, a la identificación de la amenaza de «las luces». Así, a principios del siglo XIX el tribunal reorientaba sus objetivos hacia la persecución de los ilustrados en el contexto del «cordón sanitario» que se construía frente a la Revolución Francesa (Elorza 1989). Desde entonces, se perseguirían principalmente los delitos ideológicos, fundamentados en la lectura de libros prohibidos, que García Cárcel $(1996,252)$ caracterizara como «la tentación de pensar». Así, durante los que fueron sus últimos años, el rostro que ofrecía la Inquisición española era distinto pero no por ello su influencia en la so-

\footnotetext{
2 Remitimos al origen mismo de la palabra religión en latín religare que significa unir. Respecto a la idea de que gobernar es hacer creer, véase: Foucault 2016, 315, quien atribuye la expresión a Francis Bacon. Véase también: Champion 2000, 42-67.

3 Contreras y Dedieu 1980, 37-94.
}

ciedad era menor, pues se esforzaba en preservar su poder ante las pretensiones regalistas y reforzar su vigilancia sobre la población. ${ }^{4}$

Así como la existencia de la Inquisición española fue plural, también lo fue su proceso de abolición. Su supresión tuvo una multiplicidad de cronologías y espacios, escalonados por los acontecimientos políticos desatados en la Monarquía Católica a raíz de la crisis producida por la invasión napoleónica hacia $1808 .{ }^{5}$ A pesar de la abolición decretada por Napoleón Bonaparte (1808) y por las Cortes de Cádiz (1813), el tribunal fue restituido tras la restauración absolutista de Fernando VII hacia 1814. Por su parte, las regiones insurgentes de América se apresuraron a abolir un Tribunal de la Fe que asociaban al catolicismo español despótico. ${ }^{6}$ Entretanto, el Santo Oficio era nuevamente abolido con la revolución liberal acaecida en la Península en el año 1820 siendo suprimido definitivamente por decreto real en el año 1834, tras el fin de la «Década Ominosa» (1823-1833) durante la cual las Juntas de Fe Diocesanas procuraron continuar con la persecución llevada a cabo antes por la Inquisición. ${ }^{7}$

Las supresiones de la Inquisición se realizaban así en el marco inestable de la construcción de nuevas comunidades políticas tanto en España como en América. En efecto, si la fundación del tribunal estuvo ligada a la consolidación de la Monarquía Católica como estado moderno, su abolición entrañaba una nueva forma de pensar la construcción institucional del poder de vigilar y castigar en el estado-nación. Por cierto, en España la supresión del tribunal se acompañó de la consolidación de la policía como aparato de poder (Fuentes 1990). La redefinición y construcción de nuevas comunidades políticas implicaba una interrogación acerca de la comunidad religiosa en la medida en que, durante el Antiguo Régimen hispánico, ambas coincidían. En efecto, la propia Inquisición española condensaba tensiones teológicas-políticas debido a que, a pesar de ser una autoridad delegada por el Papa, se caracterizaba por poseer un fuerte matiz monárquico. Como advirtió Kamen (1985), además de su entramado institucional que la hacía dependiente de la monarquía en lo que a nombramientos y renta respecta, la Inquisición servía a un interés religioso y a la vez político: construir obediencia entre unos fieles que, se esperaba, se comportasen como súbditos. ${ }^{8}$ En el orbe hispano persistía, pues, la concepción medieval de la Cristianitas según la cual todos aquellos que tienen fe en Cristo, y obedecen a la Iglesia, forman una comunidad que debe estar sujeta a un mismo gobierno. En aquel régimen de cristiandad, como señala Di Stefano (2000), las amenazas contra el poder temporal lo eran también contra la Iglesia. El problema teológicopolítico se desplegó así durante la etapa contemporánea en torno a la construcción de un orden secular basado en

4 Recientes estudios cuestionan la decadencia del tribunal, véanse: Torres Puga 2004; Pérez 2005; Casado y La Parra López 2013.

5 Véase: Torres Puga 2017.

6 Tcherbbis Testa 2019.

Véase: La Parra López 2017. Las Juntas de Fe se establecieron en Valencia, Tarragona, Orihuela y Zamora existiendo intentos similares también en Granada y Cartagena. Aquellas Juntas se diferenciaban de la Inquisición por depender exclusivamente de los obispos y por no contar con el apoyo explícito de la autoridad real, aunque sí contaban con el beneplácito de las autoridades locales.

8 Véase también: López Vela 1990. 
las libertades individuales. ${ }^{9}$ Como advirtió Lefort (1986), no resulta posible descifrar las transformaciones políticas de la sociedad contemporánea sin interrogarse sobre su significación religiosa. Es por ello preciso prestar atención a la historia política de la religión y, a la vez, a la historia religiosa de la política moderna para comprender cómo se redefine y disputa la noción de libertad. ${ }^{10}$

El debate sobre la supresión de la Inquisición española forjó, en parte, la conciencia liberal hispana distanciándola de la identidad política de los absolutistas y católicos tradicionalistas, especialmente de aquellos que identificándose luego con el carlismo realizaron una apología del tribunal. De modo que la Inquisición, aún suprimida, no estuvo ausente de la memoria sobre el pasado español disputada durante el siglo XIX por liberales monárquicos, conservadores, tradicionalistas, republicanos y demócratas. ${ }^{11}$ En efecto, reflexionar sobre la Inquisición suponía pensar en los rasgos del estado-nación, entre ellos su (a)confesionalidad, el rol de la Iglesia, la libertad de prensa y la libertad religiosa. En un contexto en el que, durante gran parte del siglo XIX, el catolicismo era condición de ciudadanía, la reivindicación de la libertad de cultos suponía un debate sobre los alcances de la definición del ciudadano español (Alonso García 2014). Pero fue también durante el siglo XX, en ocasión del centenario de la abolición de la Inquisición española, cuando se reelaboró una memoria sobre el lugar del Santo Oficio en la creación de la identidad nacional que, a través de distintos usos políticos del pasado, pondría en pugna relatos y proyectos políticos contrapuestos. ${ }^{12}$

En efecto, el centenario de la abolición de la Inquisición española no pudo ser sino plural, escalonado por las fechas de la inicial abolición gaditana del tribunal (22/2/1813) y la supresión definitiva mediante decreto real de la regente María Cristina de Borbón (15/7/1834). Si bien la reflexión a propósito de la Inquisición durante las primeras décadas del siglo XX ha sido analizada, la cuestión fue estudiada a través del análisis de la polémica historiográfica que se originó en torno a la «ciencia española», pero sin reconstruirse los debates desplegados en la opinión pública. ${ }^{13}$ En efecto, como demostraremos, el centenario de la abolición de la Inquisición española no pasó desapercibido en la prensa del período. Dos fechas se tornan imprescindibles para calibrar la memoria sobre la Inquisición: $1910-1912$ y 1934 , la primera referida a la definición de la soberanía nacional por las Cortes de Cádiz y la segunda a la consolidación de la monarquía liberal isabelina en contraposición a la facción dinástica carlista. Se trata, a la vez, de dos contextos políticos distintos, el primero signado por la Restauración y el segundo por la construcción de la Segunda República. Por cierto, los términos y claves del debate político de aquellos dos contextos históricos también fueron diversos. Por un lado, una España atravesada por el impacto de la crisis de 1898, preocupada por explicar las causas de su decadencia y comprometida con la búsqueda histórica de la esencia del ser español. Por otro, una España conmovida por un proyec-

\footnotetext{
9 Véase: Manent 2001, 39-54.

10 Manent 1993.

11 Véase: Cuenca Toribio 2006.

12 Para una problematización de la relación entre memoria e historia, véase: García Cárcel 2011.

13 Véanse: Áviles Fernández 1989. López Vela 1990.
}

to de transformación revolucionaria que impulsaba el laicismo. En ambos casos, como analizaremos, el anticlericalismo se constituía, aunque con distintos matices, en signo de la identidad nacional republicana (Salomón Chéliz 2002). El presente artículo busca analizar aquellos dos momentos de conmemoración desde una perspectiva comparada para dar cuenta de los cambios y continuidades en las culturas políticas y en los modos de concebir la relación entre nacionalismo y catolicismo en España. ${ }^{14}$ Pues, como argumentaremos, los distintos relatos en disputa a propósito de la Inquisición formaban parte de una problemática más amplia que se proponía reflexionar sobre las condiciones de la creencia y la (im)posibilidad de imaginar un nuevo orden político.

\section{ENTRE LA HISTORIA Y LA MEMORIA}

Desde el inicio del proceso de su supresión, la Inquisición española se consolidó como objeto de debate tanto en la historiografía como en la opinión pública, atravesados ambos campos por las disputas entre liberales y conservadores. ${ }^{15}$ Es que la polémica sobre la Inquisición habilitaba una discusión acerca de la relación entre soberanía y religión y, también, entre nacionalismo y catolicismo. Así, los primeros escritos con aspiración historiográfica basados en la utilización de documentos históricos sobre el tribunal, contemporáneos al proceso mismo de abolición, convertían la cuestión de su naturaleza jurisdiccional en el principal objeto de reflexión, pues se proponían distinguir a la Iglesia de la Inquisición. Como señala López Vela (1994), su atención se centraba en los conflictos de competencias entre la jurisdicción de los obispos y de la Inquisición, como así también en los privilegios que el poder real le había otorgado. Así Antonio Puigblanch analizaba en La Inquisición sin máscara (1811) la relación entre la jurisdicción ordinaria y la inquisitorial mientras que Juan Antonio Llorente en sus obras La Inquisición y los españoles (1812) e Historia crítica de la Inquisición en España (1817-1818) analizaba los conflictos entre los inquisidores y la jurisdicción secular. La dimensión conflictiva en torno a la relación entre Iglesia, Inquisición y Monarquía resultaba central en sus estudios.

Incluso tiempo después de su definitiva abolición, la diatriba contra la Inquisición se consolidó como característica de la cultura nacionalista liberal, aun con sus matices entre moderados y progresistas, en contraposición a la apología que de ella construía el discurso patriótico carlista. La retórica nacionalista se tensaba con la patriótica propia del tradicionalismo católico (Suárez Cortina 2014, 96). Por cierto, hacia mediados del siglo XIX, algunos historiadores comenzaron a reconstruir la historia de las minorías no católicas en la España inquisitorial. ${ }^{16}$ Por entonces se consolidaba el nacionalcatolicismo que, como advierte Suárez Cortina (2014, 90), buscaba ser equidistante del liberalismo católico y del catolicismo intransigente defendiendo la identidad católica de la nación y aceptando únicamente la tolerancia religiosa, aun cuando la crítica a la intransigencia inquisitorial no se encontraba ausente de su argumentación. Los escritos de

14 Sobre la perspectiva comparada véase: Gorelik 2004.

15 López Vela 1999, 2000.

16 Nos referimos a la obra de Amador de los Ríos Una historia de los judios (1848) y la obra Historia de los protestantes españoles (1851) de Adolfo de Castro y Rossi. Véase: Martínez Millán 2007, 9-30. 
Jaime Balmes contribuyeron en ese sentido a la conceptualización del catolicismo como símbolo de unidad de los españoles.

En efecto, la propuesta de algunos liberales progresistas, de los demócratas y republicanos, durante el llamado Bienio Progresista (1854-1856), de distinguir a la comunidad católica de la comunidad nacional introduciendo la libertad de cultos fue resistida por parte del nacionalcatolicismo y del tradicionalismo católico. ${ }^{17}$ Fue recién durante el Sexenio Democrático (1868-1874) cuando se sancionó la libertad religiosa en España. Sin embargo, durante aquellos años, los más conflictivos del siglo XIX en torno a las relaciones entre Iglesia y Estado, no se publicaron obras de relevancia sobre la historia del tribunal. Recién durante el período de la Restauración (1874-1931) nuevas obras continuaron la polémica en un contexto en el que la Constitución de 1876 reconocía la identidad católica de la nación introduciendo, a su vez, la tolerancia religiosa.

En la medida en que en la Península surgían nuevos conflictos entre la Iglesia y el Estado, la historiografía tendía a enfocar su análisis en las tensiones entre la jurisdicción inquisitorial y la secular. Pues, en palabras de López Vela $(1994,398)$, "Para los liberales del siglo XIX semejante simplificación era una manera negativa de presentar las intromisiones en el Estado por parte de la Inquisición en el pasado, que era una forma de criticar la Iglesia "reaccionaria" en su presente». Un presente en el que las críticas a la Inquisición de algunos liberales progresistas y demócratas se acompañaban abiertamente de la defensa de la libertad religiosa mientras que los republicanos proponían también el proyecto de separación de la Iglesia y el Estado. Sucede que durante la segunda mitad del siglo XIX se tendía, aunque con objetivos políticos opuestos, a equiparar Inquisición e Iglesia.

Será la obra de Menéndez Pelayo Historia de los heterodoxos españoles (1880-1882) la que desplace los ejes del debate definiendo a la Inquisición española como un instrumento de control dependiente exclusivamente de los reyes despojando al tribunal de su conflictiva dimensión teológico-política. ${ }^{18}$ En efecto, Menéndez Pelayo definió a la Inquisición como el corazón de la cultura española al punto de afirmar que cuestionarla equivalía a atacar la esencia misma de España. ${ }^{19}$ Asimismo, aquellos que rechazaban la separación Iglesia-Estado esgrimían una apología de la Inquisición española. Las obras La Inquisición de Juan Manuel Ortí y Lara (publicación del año 1877 que reunía sus artículos en El Siglo Futuro, periódico del neocatólico Cándido Nocedal), Historia verdadera de la Inquisición (1876-1877) del padre García Rodrigo e Historia de la Inquisición (1888) del jesuita Ricardo Cappa, convertían a la Inquisición en símbolo del catolicismo integrista. Como señala Halliczer (1984), esa representación caracterizará a la propaganda política derechista durante el siglo XX. En los años próximos a la proclamación de la Segunda República se publicaron algunas obras de corte republicano y anticlerical sobre el tribunal,

\footnotetext{
17 Cuenca Toribio 2006.

18 Menéndez Pelayo participó de la llamada polémica sobre la ciencia española referida a los efectos de la Inquisición en la cultura. Tras los debates publicó La ciencia española (1877). Véanse: López Vela 1996. Martínez Millán 2007.

19 Menéndez y Pelayo (1880-1882) 1956.
}

entre ellas La Inquisición española (1218-1834) publicada en 1930 por Quintiliano Saldaña y Reseña histórica de la Inquisición en España de Navarro Yébenes publicado un año después. Como analizaremos, aquellos aportes historiográficos eran recuperados por la prensa española al momento de debatir sobre la Inquisición.

Pero la Inquisición española no fue solo objeto de disputa historiográfica y debate público sino que también se convirtió en un topos recurrente en las representaciones artísticas, tanto literarias como plásticas. ${ }^{20}$ En efecto, desde los tiempos de la Reforma y la Contrarreforma, la diatriba contra el tribunal se convirtió en un componente de la llamada "Leyenda negra» destinada a cuestionar al Imperio hispánico. ${ }^{21}$ Tiempo más tarde, durante el siglo XVIII, los ilustrados polemizaron contra el tribunal español. Pero fue, como advierte Julliot (2010), durante el siglo XIX cuando emergió la figura del Gran Inquisidor en la literatura europea influenciada por el pensamiento liberal. No fue aquélla, sin embargo, una mirada exclusivamente extranjera ya que fue también una perspectiva construida por los liberales que intentaron, a ambos lados del Atlántico, disolver los cimientos del Antiguo Régimen hispánico. ${ }^{22}$

Las distintas representaciones sobre la Inquisición española que se desarrollaban en la esfera pública hispánica del período contemporáneo evidenciaban determinados usos políticos de la historia. Pues, como advierten Ruiz Torres (2001) y Álvarez Junco y de la Fuente (2017), la historia adquiere un objetivo político cada vez que los viejos conflictos permanecen vivos o bien se intenta revivirlos. En ese sentido, el debate sobre la cuestión inquisitorial en la encrucijada de los centenarios de su abolición nos permitirá, estimamos, echar luz sobre el lugar que ocupó la memoria sobre la Inquisición en el nacionalismo español.

\section{¿CELEBRAR O REPUDIAR? LA INQUISICIÓN ESPAÑOLA EN LOS CENTENARIOS DE SU ABOLICIÓN}

El momento en que un acontecimiento histórico cumple su centenario tiende a constituirse en una coyuntura en la que las representaciones políticas sobre el evento en cuestión se transforman en prácticas capaces de dar cuenta de los rasgos propios de una determinada cultura política. ${ }^{23} \mathrm{La}$ conmemoración de un acontecimiento, ya sea para repudiarlo o celebrarlo, es capaz de aglutinar una identidad en torno a determinada memoria. Como señala Moreno Luzón $(2003,208)$, «uno de los instrumentos nacionalizadores de mayor peso se encuentra en las políticas de la memoria, es decir, en la utilización del pasado nacional con fines políticos, construyendo relatos históricos que legitiman o atacan a los poderes vigentes, refuerzan la identidad propia de cada opción política y transmiten valores a la ciudadanía».

El centenario de la abolición de la Inquisición española fue, como la propia trayectoria de su proceso histórico, plural. La primera abolición fue sancionada en las Cortes de Cádiz el 22 de febrero de 1813, en plena encrucijada de la guerra por la independencia contra los franceses. Su

20 Véanse: Bethencourt 1997. Sempere Muñoz 2008. Moreno 2004.

21 Véanse: Juderías 1917, 12. García Cárcel 1992.

22 Tcherbbis Testa 2019.

23 Véase: Gillis 1994. Claramunt et al. 2001. 
primer centenario coincidió con el de las Cortes de Cádiz celebrado entre los años 1910-1912 por el gobierno de la Restauración. Así, el 24 de septiembre de 1910 se declaró día de fiesta nacional en conmemoración de la apertura de las Cortes y dos años después se celebró el 19 de marzo en honor al centenario de la promulgación de la Constitución. Como advierte Moreno Luzón (2003), el gobierno pensaba que el festejo podía dotar al nacionalismo de un poderoso mito para fortalecer a España tras el "Desastre del 98». En esa coyuntura el dilema residía en qué debía recordarse sobre el momento gaditano, si la guerra por la independencia o la construcción de un gobierno liberal.

Mientras que los liberales monárquicos celebraban la Constitución gaditana como fundamento del sistema político de la Restauración, los liberales más radicales y los republicanos reivindicaban los aspectos democráticos de la participación del pueblo y, a diferencia de los primeros, cuestionaban el caciquismo propio del sistema político de su presente (Moreno Luzón 2003). Así el republicano Rafael M. de Labra señalaba el año 1812 como fecha de nacimiento de la nación. ${ }^{24}$ La prensa republicana insistía en que la abolición del Santo Oficio se hizo «por y para honra de la nación». ${ }^{25}$ La conmemoración fue, sin embargo, resistida por las derechas católicas que, si bien celebraban la guerra por la independencia, concebían a las Cortes como un agravio a la catolicidad de la nación pues, si bien declararon la confesionalidad del Estado y aseguraron la intransigencia religiosa, promovieron la supresión de la Inquisición y la libertad de prensa. En ese escenario, el prelado de Cádiz expresó su rechazo a la celebración de unas Cortes que habían enarbolado ideas heterodoxas. ${ }^{26}$ Una voz fue indiferente a la conmemoración, la de la izquierda obrera. Como señala Moreno Luzón $(2003,217)$, «la izquierda obrera permaneció totalmente ajena a la conmemoración, a la que no prestó atención alguna. El Socialista prefería recordar en 1912 otro aniversario: el de la Comuna de París, un 18 de marzo que tapaba por completo el 19».

El centenario de la supresión de la Inquisición española por las Cortes de Cádiz no pasó desapercibido en la organización de los festejos oficiales ni tampoco en la prensa. Cuando los festejos tuvieron lugar la presidencia del Consejo de Ministros se encontraba en manos de José Canalejas, miembro del Partido Liberal, heredero de los liberales progresistas del siglo XIX, e impulsor de una política anticlerical. ${ }^{27}$ No obstante, la Iglesia tuvo un lugar importante en la conmemoración oficial del centenario gaditano, tanto en el Te-Deum como en la implementación de misas de campaña celebradas el 24 de septiembre de 1910.

24 El País. Diario republicano, Año XXVI, núm. 9028, 19/3/1912, Madrid, p. 1.

${ }_{25}$ «Un diputado inmortal de las Cortes de Cádiz. D. Joaquín Lorenzo Villanueva», El País. Diario republicano, Año XXVI, núm. 9028, 19/3/1912, Madrid, p. 1.

26 Véanse: "Senado. Sesión del día 8 de marzo de 1912», El Imparcial, Año XLVL, núm. 16173, 9/3/1912, Madrid, p. 2. "Senado. Sesión del día 8 de marzo de 1912», El Siglo Futuro. Diario católico, Segunda Época, Año VI, núm. 2206, 9/3/1912, Madrid, pp. 1-2. «Las Cortes de Cádiz. Circular del Prelado de aquella diócesis», El Siglo Futuro. Diario católico, Segunda Época, Año VI, núm. 2206, 9/3/1912, Madrid, p.1.

27 Véase: Suárez Cortina 2014, 115-124.
Así, en el marco del proyecto de construcción de lápidas en honor a los diputados liberales en Cádiz (propuesto por los españoles de Cuba, Chile y México e implementado bajo la dirección de la Sociedad Amigos del País y, especialmente por R. Labra), se destinó una en honor a Ruiz de Padrón por su labor en la abolición de la Inquisición. ${ }^{28}$ Asimismo, el monumento a las Cortes de Cádiz proyectado por el Congreso de la Nación también evocaba la abolición del tribunal, pues, según se informaba:

Este monumento consta de un alto pilar, formado por cuatro columnas, cuyos ábacos, unidos, sustentan un grupo en bronce de cuatro figuras, que sostienen un enorme infolio. Representan la Constitución. A ambos lados se abre elípticamente una exedra. A lo largo de los respaldos de los bancos corren dos grandes relieves en bronce, que representan, el de la derecha, el reconocimiento del rey Fernando VII, y el de la izquierda, la libertad de Imprenta, la abolición de la Inquisición y la Agricultura. Delante de la exedra hay dos estatuas á caballo de muy depurado gusto. ${ }^{29}$

Si bien la prensa liberal elaboraba una memoria a propósito de la Inquisición, era la prensa republicana la que le otorgaba un rol protagonista. En palabras de El País, "Sólo esta página de las Constituyentes gaditanas merece mucho más que las fiestas con que se conmemora el Centenario de la promulgación del Código Inmortal de $1812 » .{ }^{30}$ Es que en los sucesos del pasado se creía ver una respuesta ante la reacción del presente, pues se argumentaba que debía imitarse la energía con que las Cortes defendieron su obra de la conspiración reaccionaria al recordarse que «devuelven los pasaportes al Nuncio, Gravina, que se retira a Portugal, confiscan a varios prelados sus temporalidades, destierran de Cádiz a todos los canónigos comprometidos. iLo mismo que haríamos ahora!...». ${ }^{31}$ Se constataba así que la abolición del Santo Oficio "fué de tanto ó más efecto en España que la obra y la promulgación de la Constitución misma».32 Dos, sin embargo, eran los reproches que se realizaban a las Cortes: la preservación de la unidad religiosa que, se afirmaba, dejaba abierto el camino a la reacción, y el mantenimiento de Fernando VII en el trono. ${ }^{33}$

A su vez, El País cuestionaba al periódico tradicionalista El Siglo Futuro por conmemorar, en ocasión del centenario de las Cortes, a publicistas absolutistas como El Filósofo Rancio, seudónimo de Francisco Alvarado, firme defensor de la Inquisición. ${ }^{34}$ El periódico emprendía una apología del tribunal como institución propia del catolicismo romano cuestionando su abolición por parte del poder civil. El Siglo Futuro se preguntaba «¿Quién en España podrá ser enemi-

\footnotetext{
28 Véase: «El centenario de 1812». Heraldo Militar. Periódico independiente de la tarde, Año XVIII, núm. 6039, 9/9/1912, Madrid, p. 2.

29 "El monumento a las Cortes de Cádiz», La Época, Año LXIV, núm. 22287, 15/11/1912, Madrid, p.3.

30 "Las Cortes de Cádiz», El País. Diario Republicano, Año XXVI, núm. 9228, 5/10/1912, Madrid, p. 8. La nota era firmada por A. Aguilera y Arjona.

31 Ídem. Por entonces la llamada Ley del Candado, aprobada en diciembre de 1910, obstaculizó el ingreso de religiosos extranjeros a España por dos años al tiempo que retiró al embajador español ante la Santa Sede.

32 Ídem.

33 Ídem.

34 «Ranciedades», El País. Diario Republicano, Año XXVI, núm. 9068, 28/4/1912, Madrid, p.1.
} 
go de la Inquisición sino los enemigos de la fe católica ó la tradición española?».35

A pesar del rechazo del catolicismo tradicional a la celebración del centenario de las Cortes gaditanas, el gobierno de la Restauración que organizó los festejos recordó la supresión del Santo Oficio como una de las principales medidas de las Cortes a la hora de construir «lugares de la memoria» (Nora 1984). En la España de la Restauración en la que, como advierte Suárez Cortina (2014), el proyecto nacional católico aspiraba a ser predominante, la memoria de las Cortes de Cádiz favorecía la legitimación de la monarquía liberal al tiempo que la evocación de la supresión de la Inquisición empalmaba con la política tolerante de la Constitución vigente. Mientras que monárquicos liberales y republicanos coincidían en aquella celebración, eran los grupos más conservadores y tradicionalistas quienes la rechazaban. Las memorias a propósito del tribunal diferían en la medida en que también lo hacían los proyectos políticos; en todo caso, aunque en sentidos contrarios, la búsqueda era de legitimación.

Si bien en 1820 la Inquisición, que había sido restaurada por Fernando VII en 1814, fue nuevamente suprimida, aquel acontecimiento se trató de la puesta en vigencia nuevamente de la Constitución gaditana de modo que aquella fecha no aparecía fuertemente ligada al recuerdo de su abolición. EI acontecimiento que se conmemoraría en la década de 1920 sería el centenario de la muerte de Rafael de Riego. ${ }^{36}$ Por el contrario, el año 1834, fecha de la definitiva abolición de la Inquisición, sí fue evocado cien años después en la opinión pública. Aquel centenario tenía lugar en una España que, a diferencia de la monárquica de 1834 , se construía como republicana.

En efecto, la Segunda República, instaurada el 14 de abril de 1931 tras la victoria de la coalición republicano-socialista en las elecciones municipales, fue celebrada por una mayoría significativa del pueblo español que la imaginaba como la partera de un nuevo orden social que libraría al país de las injusticias provocadas por la monarquía y la dictadura de Primo de Rivera. La redefinición de España como comunidad política republicana supuso una interrogación sobre el lugar de la Iglesia católica en el Estado y la sociedad. ${ }^{37}$ Como ha advertido Tuñón de Lara (1977), la Segunda República nació con una "pesada hipoteca» en cuanto a política eclesiástica. Por un lado, recibía la herencia anticlerical del pensamiento liberal, republicano, anarquista y socialista y, por el otro, una Iglesia que, acostumbrada a la confesionalidad, se encontró conmovida y dividida ante las transformaciones en curso. ${ }^{38}$ Como advierte López Villaverde (2018), los eclesiásticos experimentaron sensibilidades diversas, como la hostilidad, la cooperación y la cautela. ${ }^{39}$

35 «Puntos de Historia. La Inquisición, las Cortes de Castilla y Aragón y Felipe II», El Siglo Futuro. Diario católico, Segunda Época, Año VI, núm. 2207, 11/3/1912, Madrid, p. 1. La nota era firmada por Manuel S. Assencio.

36 Véase, por ejemplo: "El centenario de Riego», La Voz, Diario Independiente de la noche, Año IV, núm. 1046, 2/11/1923, Madrid, p.1.

37 Véase: Cueva Merino 2014.

38 Véase: La Parra López 2001.

39 La historiografía reciente advierte sobre la necesidad de no considerar a la Iglesia como una entidad homogénea y uniforme. Véase, por ejemplo: Montero, Moreno y Tezanos 2014.
En aquel contexto de amplias expectativas, la coalición gobernante se enfrentaba al desafío de implementar un conjunto de reformas con el objetivo de modernizar el país. El programa reformista fue vasto en tanto atravesaba diversas dimensiones de la sociedad: desde la cuestión agraria, laboral y militar hasta el desafío de las autonomías regionales y la definición laica del Estado. ${ }^{40} \mathrm{~A}$ pesar de la crisis económica y social que experimentaba el país, de entre todas las medidas impulsadas, fueron las reformas laicas las que se convirtieron en el factor clave de la evolución política.

El primer Bienio Republicano (1931-1933) era heredero del pensamiento liberal progresista decimonónico que relacionaba el laicismo con la modernización y el progreso de la nación. Rápidamente se emprendió un conjunto de reformas tendientes a secularizar al Estado y la sociedad. Por entonces aún seguía vigente el Concordato firmado con la Santa Sede en 1851 que declaraba el principio de la unidad plena nacional-católica, al tiempo que la Constitución sancionada en 1876 establecía la confesionalidad del Estado y la tolerancia hacia otros cultos limitada al ámbito privado. Una de las primeras medidas del gobierno consistió en decretar en el Estatuto jurídico de la República (15 de abril de 1931) la libertad de creencias y cultos. Entretanto en las calles se manifestaba el anticlericalismo de los movimientos de extrema izquierda que se lanzaban a la quema de edificios religiosos. Tiempo después, en el mes de junio, el gobierno anunció la secularización de los cementerios, la prohibición de que las autoridades civiles participaran en ceremonias y procesiones religiosas y el proyecto de educación laica. El punto máximo de tensiones devino con la apertura de las Cortes Constituyentes comprometidas en la elaboración de una nueva carta constitucional. Tras intensos debates se promulgó una carta que preveía la aconfesionalidad del Estado, el fin del auxilio económico estatal a la Iglesia y la libertad religiosa. Por su parte, el artículo 26 establecía la disolución de la Compañía de Jesús junto a la nacionalización de sus bienes y la prohibición de la actividad docente a todas las congregaciones religiosas. Se establecía, junto a la enseñanza laica, el cementerio civil, el matrimonio civil y el divorcio.

En efecto, hacia 1933, en un contexto crispado por la reacción de la derecha católica y la violencia anticlerical, el gobierno de Azaña había logrado aplicar gran parte de aquellas medidas caracterizadas por un radical laicismo. La política eclesiástica estaba teñida de un anticlericalismo en algunos casos provocador y antipopular que resultó ser nocivo para la propia República. Así, por ejemplo, la frase de Azaña ante los incendios de mayo de 1931 «Eso, no; todos los conventos de Madrid no valen la vida de un republicano», o aquella otra "España ha dejado de ser católica», proferida en las sesiones constituyentes, revelaban un profundo anticlericalismo que, como advierte Cueva Merino (2014), incurría en la intransigencia.

Tras el viraje electoral de noviembre de 1933 la coalición republicano-socialista debió dejar paso a la nueva coalición de la centro-derecha republicana (liderada por el Partido Republicano Radical) aliada con los católicos de la Confederación Española de Derechas Autónomas (CEDA). El gobier-

40 Sobre los distintos proyectos laicos, véanse también: Álvarez Tardío 2002; Suárez Cortina 2014. 
no de la coalición radical-cedista (1933-1936) no logró, sin embargo, dar marcha atrás a las agujas del reloj en materia de legislación laica. Su política se encontraba restringida a obstaculizar la ejecución de las reformas. Sucede que la revisión constitucional solo podía debatirse en 1935 cuando debía convocarse a nuevas Cortes. Como señala Townson (2009), el gobierno republicano de entonces encaraba una política conciliadora en materia religiosa que provocaba reproches de la izquierda y tensiones con los aliados cedistas. En ese contexto se debatía sobre la Ley de Haberes Pasivos para el clero, se intentaba, aunque fallidamente, celebrar un nuevo concordato, al tiempo que se permitía la instalación de nuevas comunidades religiosas y se devolvía a los jesuitas los bienes confiscados. A su vez, la persistencia de escuelas católicas y los intentos para consolidar el sistema de educación estatal provocaban recelos. La prensa opositora a la coalición radical-cedista denunciaba la paralización de la ejecución de la legislación laica a través de una retórica fuertemente anticlerical.

Fue durante el bienio radical-cedista cuando se cumplió un nuevo centenario de la abolición de la Inquisición española (15/7/1934). El centenario no pasó desapercibido en la prensa. ${ }^{41}$ En ese escenario de pasiones clericales y anticlericales la memoria a propósito de la Inquisición española cobraba relevancia toda vez que se recordaba que había sido un instrumento clave para construir obediencia entre unos fieles que debían comportarse como súbditos. Las diferentes facciones políticas en lucha, aunque con objetivos políticos opuestos, tendían a equiparar Inquisición e Iglesia.

A diferencia de la coyuntura del centenario de las Cortes de Cádiz, cuando la memoria sobre la Inquisición se subordinaba a la gesta constituyente, en el año 1934 era la supresión de la Inquisición, en sí misma, la que cobraba protagonismo. Por otra parte, no fue el gobierno quien se propuso evocarla sino la oposición desde la sociedad civil. ${ }^{42}$ Republicanos «radicales» disidentes de la coalición en curso y grupos de izquierda, socialistas y anarquistas, junto a diferentes logias, fueron quienes transformaron aquella fecha en un centenario para ser celebrado. ${ }^{43}$

Fue, pues, la prensa republicana "radical» y de izquierda, tanto capitalina como regional, la que, desde el mes de mayo, informó al público lector sobre los preparativos para celebrar el centenario de la abolición del Santo Oficio, presididos por Belén de Sárraga. ${ }^{44}$ Así, por ejemplo, desde el diario republicano de impronta lerrouxista La Voz de Menor$c a$, órgano principal del Partido Radical en las Islas Baleares, se informaba, en primera plana y acompañando las noticias

41 Sobre la prensa del período, véase: Checa Godoy 1989.

42 Sobre las celebraciones en la Segunda República, véase: Campos Pérez 2016.

43 Utilizamos aquí el término republicanos «radicales» no en un sentido partidario sino cultural aludiendo, como indica Cueva Merino (2014, 95-96), a una subcultura política del republicanismo, opuesta a la vertiente reformista, que hace uso de una retórica anticlerical fundada en una valoración negativa del catolicismo e intransigente hacia el mismo; así su propuesta de separación de la Iglesia y el Estado se concebía como el sometimiento de la primera al segundo. Entre aquellos republicanos «radicales» podemos encontrar a republicanos federales, lerrouxistas, radical-demócratas, radical-socialistas y miembros de las sociedades de librepensamiento.

44 Véase: Ramos 2002. Véase, entre otros: Ahora, Año V, núm. 1064,16/5/1934, Madrid, p. 21. La Libertad, Año XVI, núm. 4414, 16/5/1934, Madrid, p. 7. sobre las dictaduras europeas, que la Agrupación de Veteranos de la República invitaba «a todas las organizaciones, sin distinción de matices ideológicos, desde los liberales a los comunistas, tanto de Madrid como de otras provincias» a reunirse para organizar festejos en conmemoración del centenario de la abolición de la Inquisición, pues se argumentaba que resultaban imprescindibles «en el momento político y social de España». ${ }^{45}$ Los intentos por conmemorar la abolición de la Inquisición guardaban pues relación con la marcha política del primer semestre de 1934, impulsados por el temor hacia la paralización de la ejecución de las medidas laicas. La oposición a la Inquisición buscaba amalgamar la posición anticlerical de los distintos grupos en pugna que, en gran parte, se habían mostrado divididos en la competencia electoral pasada. La conmemoración del centenario adoptará un tono decididamente opositor a la coalición gobernante.

La Libertad, uno de los diarios republicanos de izquierda más difundidos en Madrid, informaba que la primera reunión organizativa había tenido éxito pues contó con la presencia de las delegaciones de «todos los partidos republicanos» (radical socialista, radical demócrata, federal pimargalliano, federal autónomo, Libre Pensamiento, Asociación Republicana Femenina, Unión Republicana Femenina, Fraternidad Cívica, Femenina Educación Cívica) y logias masónicas; días después se informaba también la adhesión de la izquierda. ${ }^{46}$ Sin embargo, cabe advertir que no se registraba la participación del Partido Republicano Radical en la organización de los festejos. En aquellas reuniones se acordó la celebración de un acto nacional organizado por una comisión integrada por delegados de partidos y asociaciones republicanas. ${ }^{47}$ Los festejos comprenderían «conferencias en varios locales de partidos políticos y sociales, verbena, proyecciones, conciertos musicales, impresión de aleluyas alusivas y folleto historia de los tormentos y táctica del citado Tribunal». ${ }^{48}$

Por su parte, la prensa confesional se burlaba de los festejos que organizaban "los veteranos de la república». El periódico primoriverista La Nación cuestionaba la celebración como obra de la masonería para perpetuar la «Leyenda Negra». ${ }^{49}$ Al respecto el Dr. José María Albiñana, férreo opositor de la República, fundador del Partido Nacionalista Español y por entonces diputado monárquico por Burgos, argumentaba que: «el 15 de julio de 1834 ya no había nada inquisitorial que abolir, porque todo estaba abolido. Los inventores de este truco histórico pueden "enfundar-

45 La Voz de Menorca, diario republicano desde su fundación, Año XXIX, núm. 9283, 1-6-1934, Mahón, p. 1.

46 La Libertad, Año XVI, núm. 4430, 3/6/1934, Madrid, p. 7. Véase también: La Libertad, Año XVI, núm. 4444, 20/6/1934, Madrid, p. 4 y 6 . Entre sus redactores se encontraba Eduardo Ortega y Gasset e Indalecio Prieto.

47 Heraldo de Madrid, Año XLIV, núm.15084, 4/6/1934, Madrid, p.13. En aquel ejemplar el humorista Sawa identificaba a Gil Robles con el Santo Oficio.

48 Heraldo de Madrid, Año XLIV, núm. 15105, 28/6/1934, Madrid, p.2.

49 La Nación, Año X, núm. 2628, 30/5/1934, Madrid, p. 3. Se trata del periódico fundado por el general Miguel Primo de Rivera. Durante la Segunda República defendió a la ultraderecha monárquica polemizando con los dirigentes de la CEDA cuestionando su postura accidentalista en cuanto a las formas de gobierno y mostrándose próximo al nazismo. 
se" la fecha "gloriosa" y reservarla para mejor ocasión». ${ }^{50}$ De hecho, recriminaba a los republicanos no conmemorar «los tremendos crímenes» perpetrados por la «siniestra revolución francesa» a cuyos tribunales define como "santo oficio laico». ${ }^{51}$ Por cierto, Albiñana había publicado un año antes su libro Confinado en las Hurdes (Una víctima de la Inquisición republicana) en el que denunciaba la represión del gobierno republicano-socialista representándose como su víctima. En el mismo sentido, el diario católico afín a la CEDA, La Gaceta de Tenerife constataba: «Tiene gracia. Los veteranos no se dan cuenta de que la Inquisición, comparada con el equipo de Casas Viejas, venía a ser la Matritense de Caridad $» .{ }^{52}$ Por cierto, los redactores se referían a la masacre perpetrada por la Guardia Civil en la localidad de Casas Viejas, perteneciente a la provincia de Cádiz, que había protagonizado una insurrección anarquista. En efecto, el violento acontecimiento produjo una crisis de legitimidad en el gobierno republicano-socialista de Azaña. ${ }^{53}$ Se buscaba así convertir los trágicos sucesos de Casas Viejas en parte de la leyenda negra contra la Segunda República pues se la acusaba de engendrar un "Santo Oficio laico» que superaba la «táctica inquisitorial de antaño». ${ }^{54}$

En medio de aquellas controversias, quienes organizaban los festejos intentaron dotar a los mismos de una impronta oficial. Así, el señor Francisco Cantos Abad, miembro de la comisión gestora de la Diputación Provincial de Madrid y perteneciente al Partido Republicano Federal, solicitó a la diputación que concurriera a las celebraciones. ${ }^{55}$ Había, sin embargo, quienes consideraban irónico que se festejase la abolición de un tribunal cuyos procedimientos de censura seguían vigentes. Así desde el periódico La Tierra, afín a la extrema izquierda, se ironizaba: "Solo le hace falta proponer una cosa, y es: que para organizar las fiestas con que se ha de celebrar "la abolición del Santo Oficio" se nombre una Comisión cuyo presidente efectivo sea Martínez Anido, y el honorario Gil Robles». ${ }^{56}$ Desde La Tierra, no se esperaba que la celebración contara con el apoyo oficial, pues se consideraba paradójico en el contexto de la alianza del gobierno republicano con la CEDA. Por cierto, la asociación del líder cedista Gil Robles con el Santo Oficio era recurrente en la prensa opositora. La condena común hacia el Santo Oficio no impedía que se expusieran las tensiones entre las distintas fuerzas políticas que coincidían en los festejos.

La celebración fue, de todos modos, un acto de los partidos republicanos opositores a la coalición gobernante, al cual distintas personalidades políticas adherían advirtiendo la preocupación de que el pasado inquisitorial se reinventara. Así, el republicano Diego Martínez Barrio, quien tras la

50 Ídem. Sobre Albiñana, véase: Gil Pecharromán 2000.

51 Véase también: La Nación, Año X, núm. 2669, 17/7/1934, Madrid, p. 2.

52 La Gaceta de Tenerife, diario católico-órgano de las derechas, núm. 7.733, 19/6/1934, Santa Cruz de Tenerife (Canarias), p. 4.

53 Sobre Casas Viejas, véase: Gutiérrez Molina 2015.

54 La Gaceta de Tenerife, diario católico-órgano de las derechas, núm. 7749, 7/7/1934, Santa Cruz de Tenerife (Canarias), p. 1.

55 Heraldo de Madrid, Año XLIV, núm. 15097. 19/6/1934, Madrid, p.5. Por cierto, el alcalde de Madrid Pedro Rico, afín al partido radical-demócrata, dio su apoyo a los festejos. Véase: Heraldo de Madrid, Año XLIV, núm. 15.105, 28/6/1934, p. 2.

56 La Tierra, Año V, 20/6/1934, Madrid, p. 1. alianza con la CEDA abandonó el Partido Republicano Radical fundando el Partido Radical Demócrata, afirmaba:

No debe limitarse la acción de la democracia a juzgar aquel acontecimiento histórico, sino a prevenir y a evitar el futuro. Ciego será quien no vea que estamos ante el propósito de restablecer una nueva modalidad inquisitorial con finalidades idénticas a las de hace siglos. Se quiere consagrar el poder político y humano de la Iglesia y someter a su dirección la gobernación de los pueblos y la conciencia individual. ${ }^{57}$

La conmemoración parecía devenir en una necesaria acción preventiva. En palabras del escritor Ramón Gómez de la Serna: «Está bien que se señale que todo eso ha quedado detrás en el tiempo y se apague con exaltación y brillantez ese remusgo de temor, que pasa por las conmemoraciones de abolición, de que algo de eso pueda volver». ${ }^{58}$ Se planificaba que los festejos tuvieran lugar en los distintos locales partidarios desde el sábado 7 al domingo 15 de julio en una semana a la que se adjetivaba como «laica» contra la reacción. ${ }^{59}$ La celebración del centenario se concebía como un modo de denunciar la posible clericalización de la República ante el accidentalismo que manifestaba la derecha católica y, a la vez, como un modo de repudiar el avance del autoritarismo en Europa.

Al calor de la conmemoración, la cuestión de la Inquisición se concebía, aunque desde distintas perspectivas, como una problemática actual. ${ }^{60}$ Así el periódico republicano de izquierda La Región expresaba el temor de que «renazca bajo la forma de dictadura fascista-clerical la Santa Inquisición». ${ }^{61}$ Por su parte, el 14 de julio de 1934, La Libertad dedicaba en su primera plana una nota sobre el Santo Oficio bajo el rubro "Temas de actualidad». En ella el periodista Luis Astrana Marín definía al tribunal como «el terror de la conciencia libre» y causa principal de la decadencia española. ${ }^{62}$ Caracterizaba, además, a la Inquisición como un tribunal de jurisdicción mixta, dependiente tanto de la Monarquía como de la Iglesia. En aquel mismo ejemplar se publicaba una nota titulada «El centenario de la abolición del Santo Oficio» donde se informaban los festejos organizados por el grupo cultural de la barriada de Ventas y sus limítrofes. La celebración, que se había iniciado en Madrid con un festival en el club Natación Florida, ${ }^{63}$ era presentada como necesaria «ante los avances de la reacción, que pre-

57 Véase: La Voz, Año XV, núm. 4204, 21/6/1934, Madrid, p.8. Sobre Martínez Barrio, véase: Álvarez Rey 2000.

58 «Recuerdo de la Inquisición», Luz, Diario de la República, 14/7/1934, Madrid, p.7.

59 Sobre las conferencias pronunciadas en los locales partidarios, véase: La Libertad, Año XVI, núm. 4462, 11/7/1934, Madrid, p. 7. Entre las figuras que presidían los actos encontramos a D. José María Puig Asprer, Doña Dolores Mera de Posadas, Don José Ballester Gonzalvo, Don Julío Macías, Don Joaquín Nogueras, Doña Belén Sarraga, Sr. Don Onrubia, Ricardo Baroja, Don José Rocamora. Véase: La Libertad, Año XVI, núm. 4466, 15/7/1934, Madrid, p. 3.

60 Véanse: La Libertad, Año XVI, núm. 4451, 28/6/1934, Madrid, p. 7. El Liberal, Año XXXIII, núm. 10915, 29/6/1934, Murcia, p. 2. La Libertad, Año XVI, núm. 4462, 11/7/1934, Madrid, p. 7. La Libertad, Madrid, Año XVI, núm. 4463, 12/7/1934, p.4. La Libertad se presentaba como el periódico «de más grandes tiradas».

61 La Región, Año XI, núm. 3921, 13/7/1934, Santander, p. 1.

62 La Libertad, Año XVI, núm. 4465, 14/7/1934, Madrid, p. 1.

63 Heraldo de Madrid, Año XLIV, núm. 15112, 6/7/1934, Madrid, 
tende resucitar el espíritu de los Torquemadas". ${ }^{64}$ Se informaba, en ese sentido, la organización de un culto memorial dedicado a las víctimas de la Inquisición a celebrarse en la iglesia reformada de la calle Beneficencia el día domingo 15 de julio. De igual modo, se preveía una conmemoración en el paraninfo Colegio El Porvenir en el que participaría el coro evangélico de Madrid. Los cultos disidentes cobraban así protagonismo en la celebración. Se informaba también de la planificación de un gran mitin en el cine Pardiñas que contaría con diversos oradores, entre ellos Eduardo Ortega y Gasset y Belén de Sárraga.

Por su parte, el periódico republicano moderado Ahora publicaba el día del centenario de la abolición una nota en la que se repasaba la historia del tribunal, basada en los trabajos de Juan Antonio Llorente, cuestionándose la imagen que desde el extranjero se elaboraba de España como tierra de Inquisición, aunque se admitía que constituía "la base más cierta de la leyenda negra». ${ }^{65}$ Se evocaba, en efecto, el rechazo popular a la implantación del Santo Oficio señalando que si el pueblo español hubiera adoptado una actitud más enérgica, habría podido evitar su instalación. ${ }^{66} \mathrm{Se}$ recordaba, también, la oposición de la reina Isabel hacia el tribunal al tiempo que se denunciaba su antijudaísmo. Tal cuestionamiento cobraba relevancia, según el redactor, al constatarse:

La suprema inhumanidad de nuestra época; una época en la que las «inquisiciones» revolucionarias o nacionalistas de ahora han superado todas las crueldades y todos los crímenes de aquella "España negra», cuya leyenda podemos, al cabo de un siglo, afrontar con mucho menos rubor que otros pueblos - Rusia, Alemania - tienen que hacer frente a sus procedimientos inquisitoriales de esta hora que estamos viviendo. ${ }^{67}$

El periódico cuestionaba, así, a través de la Inquisición a la intransigencia, cualquiera sea su signo político. Por su parte, el diario republicano de izquierda Heraldo de Madrid advertía que «de nada servirán leyes de espíritu liberal y justo, mientras haya gobiernos que las vulneren ${ }^{68}$

Muchos eran los periódicos de izquierda que daban cuenta de las celebraciones. ${ }^{69}$ Como ya habrá advertido el lector, los festejos se difundían tanto en la prensa capitalina como en la regional. ${ }^{70}$ Así, por ejemplo, el periódico La Prensa de Santa Cruz de Tenerife afirmaba que se conmemoraba «una de las fechas más trascendentales de la historia de

\footnotetext{
64 La Libertad, Madrid, Año XVI, núm. 4465, 14/7/1934, p. 7.

65 Ahora, Año V, núm. 1116, 15/7/1934, Madrid, p. 13.

66 Ídem.

67 Ídem.

68 Heraldo de Madrid, Año XLIV, núm. 15120, 16/7/1934, Ma-
} drid, p.13. Fue una publicación vespertina con diversas ediciones diarias. Fue fundada con una tendencia demócrata por Felipe Ducazcal (1845-1891) convirtiéndose en órgano del Partido Liberal, manteniendo su tendencia demócrata y anticlerical, siendo partidario de la confrontación bélica en 1898. Durante los primeros años del siglo XX se constituyó en una de las publicaciones diarias de mayor tirada. Se manifestó contrario a la dictadura de Primo de Rivera y durante la Segunda República se constituyó en defensor de los partidos republicanos de izquierda siendo suspendida por su postura socialista en 1934

69 Véanse: La Vanguardia, Año LIII, núm. 21.951, 17/7/1934, Madrid, p. 23. Véase también: La Región, Año XI, núm. 3921, 13/7/1934, Santander.

70 Véase también: El Anunciador Comercial. Semanario cultural de anuncios y noticias, Año X, núm. 557, 21/7/1934, Sueca.
España». ${ }^{71}$ Para conmemorar la supresión, el periódico dedicaba un elogio a la figura del clérigo liberal canario Ruiz de Padrón quien en las Cortes de Cádiz se pronunció a favor de la abolición del tribunal; la memoria se teñía así del orgullo por la identidad regional.

Asimismo, el centenario de la abolición de la Inquisición atrajo la atención de la prensa incluso días después de los festejos. Así, por ejemplo, Heraldo de Madrid publicó un artículo titulado "Ante el centenario de la abolición del Santo Oficio» en el que se reproducían algunos lienzos de la colección de pinturas sobre la Inquisición española del artista decimonónico flamenco Franz Vinck. ${ }^{72}$ Curioso es también señalar que las pinturas de Vinck fueron reproducidas en la revista Macrocosmo del mes de septiembre de 1934, publicación naturista y espiritista crítica del fascismo y nazismo. Por cierto, aquel centenario era recordado, a la vez, en el extranjero. ${ }^{73}$

Se producía así un uso partidario de la memoria a propósito del tribunal, por un lado, inserto en un entramado propagandístico en contra de la alianza de la centro-derecha republicana con la CEDA y, por otro lado, denunciando la creación de un "Santo Oficio laico» durante el bienio republicano-socialista. Sin embargo, había quienes cuestionaban que la conmemoración fuera partidaria. Así, desde El Sol, el publicista Melchor Fernández Almagro argumentaba que «utilizar una conmemoración histórica al dictado de una u otra noción política es mal sistema», más aun cuando se reproducían los tópicos de la leyenda negra afectando el buen nombre de España. ${ }^{74}$ No faltaba quien afirmaba que «las fiestas por la abolición del santo oficio eran irrisorias en cantidad y calidad». ${ }^{75}$ Por cierto, desde las páginas de La Libertad el escritor Pedro de Répide constataba que «la conmemoración no ha tenido trasunto popular, ni aun se ha generalizado puertas adentro de algunos círculos políticos, no todos los republicanos" aunque no dejaba de enfatizar que «el centenario de la abolición del Santo Oficio se ha celebrado en España y fuera de España de una manera demasiado viva", si bien reprochaba el fanatismo anticlerical de algunos de los eventos reconociendo que «los extremos se tocan» y que "el temperamento español propende hacia lo inquisitorial». ${ }^{76}$

Por su parte, la prensa monárquica rechazaba la celebración de la abolición de la Inquisición española. Así lo hacía,

71 La Prensa, Año XXIV, núm. 9317, 22/7/1934, Santa Cruz de Tenerife, p. 5.

${ }_{72}$ "Ante el centenario de la abolición del Santo Oficio. Historia y origen de diecinueve lienzos del pintor Franz Kasper Hubert Vinck representación de los diversos tormentos inquisitoriales», Heraldo de Madrid, Año XLIV, núm. 15.121, 17/7/1934, Madrid, p. 2. Aquellas pinturas también se reproducían en la publicación El Mundo gráfico (Año XXIV, núm. 1185, 18/7/1934, Madrid).

73 Véase, por ejemplo: Baruch Braunstein «Spanish Inquisition died out just one hundreed years ago; Its Long and Cruel War on Those It Termed 'Heretics' Is Recalled by Relics and Ruins Still Standing in Parts of Spain", The New York Times, 16/12/1934, New York, p. 17.

74 "Centenario de la abolición del Santo Oficio», El Sol, Año XVIII, núm. 5274, 11/7/1934, Madrid, p.1.

75 Véase: La Época, Año 86, núm. 29508, 16/7/1934, Madrid, p. 6. Se publicaría allí una apología al tribunal, véase: «El centenario de la Inquisición», La Época, Año 86, núm. 29514, 23/7/934, Madrid, p. 3. Se trata de una publicación afín al Partido Conservador que hacia 1933 adopta una posición cercana a Acción Española.

76 La Libertad, Año XVI, núm. 4468,18/7/1934, Madrid, p.1. 
entre otras, la revista Acción española, dirigida por Ramiro de Maeztu, intelectual de la generación del 98 que por entonces había virado hacia posiciones reaccionarias. ${ }^{77}$ En las páginas de Acción española, al igual que desde las del periódico tradicionalista El Siglo Futuro, se cuestionaba aquella celebración argumentándose que, por el contrario, el pueblo español debía conmemorar las matanzas de frailes que habían ocurrido también hacia el año $1834 .{ }^{78}$ El Siglo Futuro advertía que el 15 de julio se encontraba situado entre otras dos fechas propias de los detractores de la Inquisición, el 14 de julio, conmemoración de la "Revolución francesa anticristiana», y el 17 de julio, inicio de las matanzas del año 1834, episodio "anti-católico» y "anti-español». ${ }^{79}$ Se reivindicaba, pues, a la Inquisición como creación de la conciencia nacional española y se lamentaba que «en Europa, las guerras de religión hicieron imposible la constitución de ese Estado totalitario» que, se admitía, se intentaba por entonces implantar en Europa. ${ }^{80}$ La vigilancia inquisitorial era así elogiada en tanto concepción totalitaria del poder. A su vez, el periódico monárquico $A B C$ de Sevilla publicaba una nota de Ramiro de Maeztu que insistía en el rechazo de las celebraciones anticlericales. ${ }^{81}$ Maeztu fundamentaba su postura en los estudios críticos de la interpretación de Juan Antonio Llorente, especialmente aquellos recientemente publicados como los del mexicano Don Alfonso Junco y de los españoles Ramírez de las Casas y García Rodrigo. ${ }^{82}$

Así lo hizo también El Siglo Futuro cuestionando el artículo que Luis Astrana Marín había publicado en La Libertad recurriendo a los argumentos propios de la interpretación que Menéndez Pelayo construyó sobre el Santo Oficio. ${ }^{83}$ Desde las páginas del periódico se cuestionaba, a su vez, a la redacción de El Liberal a la cual se acusaba de «inventar la Inquisición española», pues se aseguraba que el tribunal tal como era descripto por la prensa nunca existió. ${ }^{84}$ Por cierto, El Siglo Futuro publicitaba las nuevas ediciones de las obras de Juan Manuel Ortí y Lara (La Inquisición, 1877) y Ricardo Cappa (La Inquisición española, 1888), que reivindicaban al tribunal como instrumento capaz de preservar la unidad católica como esencia de la nación española. ${ }^{85} \mathrm{Se}$

77 Para el caso de la prensa regional, véase: El Gallo crisis. Libertad y Tiranía, Virgen de agosto de 1934, Orihuela, núm.2, pp. 25-26.

78 Véase: "Doble centenario», en Acción española, revista quincenal, Tomo X, núm. 56 y 57, 1/7/1934, Madrid, pp. 113-123. La polémica continúo, véase: Agustín G. de Amezúa, «Postulados inquisitoriales», en Acción española, revista quincenal, Tomo X, núm. 58 y 59, 1/8/1934, Madrid, pp. 336-344. Véase también: «1834-1934. Dos centenarios. La abolición del Santo Oficio - La matanza de los frailes», El Siglo Futuro, Año LIX, núm. 18049, 17/7/1934, Madrid, p.1.

79 «Fechas. 17 de julio de 1834», El Siglo Futuro, Año IX, núm. 18049, 17/7/1934, Madrid, p.3.

80 Véase también: Pedro Sainz Rodríguez, «La tradición nacional y el Estado futuro - Inquisición y guerras de religión», en Acción española, revista quincenal, Tomo X, núms. 60 y 61, 1/9/1934, Madrid, pp. 519-520.

81 Véase: Ramiro de Maeztu, «La Inquisición», $A B C$ Diario llustrado, Año XXX, núm. 9.721, 21/7/1934, Sevilla, p. 3. Sobre el itinerario intelectual de Ramiro de Maeztu, véase: Jiménez Torres 2015.

${ }_{82}$ Refiere aquí al folleto de Don Alfonso Junco titulado Inquisición sobre la Inquisición.

83 Véanse: El Siglo Futuro, Año LIX, núm. 18.059, 28/7/1934, Madrid. El Siglo Futuro, Año LIX, núm. 18.061, 31/7/1934, Madrid, p. 1.

${ }_{84}$ El Siglo Futuro, Año LXI, núm.18.045, 12/7/1934, Madrid, p. 1.

85 Véase: El Siglo Futuro, Año LXI, núm. 18.046, 13/7/1934, Madrid, p.5. Se publicitaba también la venta de insignias carlistas. elogiaba, asimismo, la obra Historia verdadera de la Inquisición de Francisco Javier García Rodrigo que, a diferencia de las anteriores, se fundamentaba en un análisis documental del tribunal aun cuando, al igual que aquellas, reivindicaba el aporte del tribunal a la preservación de la ortodoxia y la unidad política y social de España; tarea que, por cierto, el autor consideraba necesaria en su presente ante la amenaza de nuevas herejías (liberalismo, socialismo, federalismo y anarquismo). ${ }^{86}$

En la prensa monárquica se apelaba, pues, a los estudios recientes acerca del tribunal para concluir sobre la importancia de la colaboración entre la Monarquía y la Iglesia en la preservación de la unidad española, pero, a la vez, para señalar la importancia de emprender un análisis documentado del tribunal (aunque desconociendo los aportes en ese sentido de trabajos previos como el de Juan Antonio Llorente). Así desde Acción española, el jurista Agustín G. de Amezúa impulsaba la creación de "una Sociedad de estudios inquisitoriales» aclarando "que nadie pide ni puede pedir la apología de la Inquisición, sino su historia» aunque se reconoce sus beneficios principalmente en torno a la «unidad espiritual». ${ }^{87}$ Fueron, de hecho, los autores católicos, especialmente eclesiásticos, quienes impulsaron durante aquellos años el trabajo con el archivo inquisitorial publicando fuentes hasta entonces inéditas. ${ }^{88}$ En efecto, como advierte López Vela $(1990,286)$, «la propuesta católica de investigación e interpretación del Santo Oficio» surgió en los años de la Segunda República. La prensa católica monárquica manifestaba, pues, la necesidad de impulsar estudios históricos sobre la Inquisición en un contexto atravesado por las memorias cruzadas sobre el tribunal.

El debate sobre la memoria a propósito de la Inquisición española desplegado en la opinión pública no se encontraba, pues, aislado de los proyectos políticos en pugna de la coyuntura. Por un lado, se exponía un uso político del pasado del Santo Oficio como elemento de propaganda anticlerical que permitía asociar a la Iglesia con la reacción, condenar a la coalición radical-cedista e intentar desplazar al catolicismo como seña de identidad nacional. Por otro lado, se evocaba a la Inquisición como instrumento de preservación de la esencia católica del pueblo español al tiempo que se manifestaba la necesidad de un estudio histórico sobre el tribunal que, tras la Guerra Civil, dará forma a una historiografía integrista vinculada a ámbitos eclesiásticos. Pero también había quienes, desde perspectivas moderadas, señalaban que la intransigencia no tenía un único rostro.

Lo cierto es que la polémica por la política religiosa incidió en la agudización de la crisis de la Segunda República. Aquellas políticas lejos de fortalecer al gobierno democrático contribuyeron a crear una crisis en la sociedad civil. El factor religioso resultó determinante en aquella crisis ya que la política laica, a pesar de tener un objetivo modernizador, contribuyó a fortalecer los legados del pasado, ya sea tanto las pretensiones hegemónicas del catolicismo como las as-

86 El Siglo Futuro, Año LIX, núm. 18.065, 4/8/1934, Madrid, p. 4.

87 Agustín G. de Amezúa, "Postulados inquisitoriales», en Acción española, revista quincenal, Tomo X, núm. 58 y 59, 1/8/1934, Madrid, p. 343.

88 Entre aquellos estudios se encontraban, entre otros, los trabajos monográficos de B. Llorca publicados en la revista Estudios eclesiásticos. 
piraciones del anticlericalismo radical. Como advirtió Robinson (1974), la política anticlerical del Primer Bienio impulsó la consolidación de la derecha como fuerza política que rápidamente convocó a los católicos a la unidad y promovió una campaña nacional por la revisión de la Constitución. Las elecciones de febrero de 1936 arrojaron un resultado inesperado: la victoria del Frente Popular. Pero para entonces las tensiones sociales se habían acrecentado a punto tal de desembocar en la trágica Guerra Civil (1936-1939).

En cierto modo podría afirmarse que las representaciones contrapuestas en torno a la Inquisición resultaron claves en el proceso de construcción del mito de las dos Españas. Como ha advertido Abellán $(1984,548)$ :

Las «dos Españas» no son, pues, dos Españas reales, sino el producto intelectual de sectores encontrados de la sociedad española, uno de los cuales se arroga la pretensión de ser el único válido, pretensión a partir de la cual le niega al otro el pan y la sal. En realidad, esta teoría de "las dos Españas» no es sino el primer producto de una «mentalidad inquisitorial» con la que se pretende sustituir a la Inquisición.

La mentalidad inquisitorial no resultaba, pues, ser solo asunto del pasado en la Europa de entreguerras.

\section{CONCLUSIÓN}

La Inquisición española, destinada a construir obediencia entre unos fieles que debían comportarse como súbditos, ocupó un lugar clave en la Monarquía Católica. La cuestión inquisitorial remitía a la compleja relación entre religión y política y, especialmente, al vínculo entre la Iglesia y la Monarquía. El Tribunal de la Fe se encontraba inserto en tensiones, a la vez políticas y religiosas, que se desplegaron durante el período contemporáneo cuando la sociedad española se enfrentó al desafío de reinventar los cimientos del régimen político y construir un orden secular basado en las libertades individuales.

Desde el proceso mismo de su abolición, a lo largo de las primeras décadas del siglo XIX, la Inquisición española cobró fuerza como símbolo de intolerancia e ideal de unanimidad convirtiéndose en un objeto de polémica, no solo en la historiografía sino también en la memoria colectiva, cada vez que se ponía en debate la definición de la libertad de los españoles. La supresión del Santo Oficio formó parte del proceso de construcción de una nación liberal basada en la noción de una ciudadanía católica. En efecto, su supresión no se acompañó de la promulgación de la libertad religiosa, que sería reconocida años después durante la experiencia del Sexenio Democrático y de la Segunda República.

En el presente artículo analizamos las memorias construidas a propósito de la Inquisición española en la coyuntura del centenario de su abolición, escalonado entre los años 1912 y 1934, en la encrucijada entre la Monarquía y la República. Aquellas dos coyunturas centenarias nos han permitido reconstruir el modo en que la actividad conmemorativa no solo apelaba al pasado sino también a proyectos concretos de futuro en la medida en que las conmemoraciones se constituyeron en momentos capaces de aglutinar identidades partidarias y proyectos nacionales contrapuestos en torno a la confesionalidad y la secularización. Hemos procurado demostrar que aquellas memorias en disputa desple- gadas en la opinión pública formaban parte de un debate más amplio sobre la relación entre la identidad nacional y el catolicismo y, también, sobre la (im)posibilidad de imaginar un nuevo orden político. El interrogante que emergía en la polémica consistía, en última instancia, en si era acaso legítimo reivindicar la identidad nacional sin la defensa de la unidad católica. En ese sentido, las memorias contrapuestas no solo se disputaban el significado histórico del Tribunal de la Fe en la construcción de la idea de España sino también en la (i)legitimidad de la definición confesional del Estado. Las representaciones sobre la Inquisición se traducían en prácticas políticas disímiles.

La conmemoración de la primera abolición de la Inquisición española tuvo lugar en el año 1912 como parte de los festejos en homenaje a los cien años de las Cortes de Cádiz. La celebración de las Cortes gaditanas se presentaba, tras el Desastre del 98, como una forma de legitimar a la monarquía liberal del período de la Restauración, a la vez que la supresión del tribunal se mostraba como antecedente de la tolerancia religiosa promulgada en la Carta de 1876. Los festejos acompañaban así el sentir del nacionalcatolicismo propio del gobierno de la época. Se procuró, en ese sentido, que la conmemoración tuviera un efecto cohesionador pues desde el gobierno se representaba a la nación liberal como producto de la gesta gaditana. En aquella conmemoración coexistían liberales monárquicos, republicanos y demócratas, aunque no así los sectores más conservadores y tradicionalistas que concebían a las Cortes como atentatorias al catolicismo entendido como la esencia de la identidad española. En ese contexto, el centenario de la abolición del tribunal podía ser comprendido como parte de un largo proceso histórico de construcción de la libertad o como parte de un ataque al poder de la Iglesia. Si bien la prensa liberal elaboraba una memoria a propósito de la Inquisición, era la prensa republicana la que le otorgaba un rol protagonista a su abolición en los festejos en honor a Cádiz. De ese modo, la prensa republicana pretendía impugnar el proyecto del nacionalcatolicismo condenando, a través de la Inquisición, al catolicismo como responsable de la decadencia de España. Pues, desde la perspectiva republicana la abolición del tribunal se concebía como un paso necesario, aunque no suficiente, para la construcción de una España laica. De modo que las memorias a propósito del tribunal diferían en la medida en que también lo hacían los proyectos políticos.

Pero si en 1912 la conmemoración de la abolición de la Inquisición se subordinaba al acontecimiento mayor del nacimiento de un orden constitucional, fue en 1934 cuando el acontecimiento adquirió protagonismo en sí mismo. Como analizamos, en 1912 era el propio gobierno quien impulsaba los festejos por el centenario de las Cortes de Cádiz para legitimar a la monarquía liberal vigente. A diferencia de aquella coyuntura, en 1934 fueron los grupos republicanos «radicales» disidentes de la coalición gobernante y grupos de izquierda, socialistas y anarquistas, junto a diferentes logias, quienes conmemoraban el centenario de la abolición definitiva del tribunal para celebrar la construcción de una República laica y, al mismo tiempo, repudiar el poder que las derechas católicas habían logrado conseguir tras el viraje electoral de noviembre de 1933. La organización de los festejos por parte de fuerzas partidarias enfrentadas hacia poco en la competencia electoral buscaba convertir 
a la celebración anticlerical en un factor cohesionador de un proyecto de secularización y transformación laica de la sociedad. En efecto, a pesar de que existieron sectores que buscaron dotar a la celebración de una impronta oficial, fue desde la sociedad civil que se proyectaron los festejos en los que cultos disidentes tuvieron participación. La memoria republicana a propósito de la Inquisición española cobraba, pues, relevancia toda vez que se recordaba que había sido un instrumento clave para construir obediencia entre unos fieles que debían comportarse como súbditos. La conmemoración adquiría así un sentido ambiguo: se conmemoraba para celebrar el régimen republicano y a la vez repudiar al gobierno vigente en un contexto en el que se temía la paralización de la ejecución de las medidas laicas y la clericalización de la República ante la alianza radical-cedista. La insistencia en la celebración de la abolición de la Inquisición parecía demostrar el temor por un pasado presente.

En ese movimiento pendular de la construcción política de España, jalonado por los centenarios, entre la monarquía liberal y la república, hay, sin embargo, una continuidad persistente que es el antiliberalismo del tradicionalismo católico. Un tradicionalismo que, paradójicamente, coincidiría con las posturas republicanas de izquierda en equiparar Inquisición e Iglesia. Equiparación que estaba ausente en los festejos por el centenario de las Cortes de Cádiz pues, como señalamos, a pesar de la resistencia de algunos obispos, la Iglesia tuvo participación en la celebración oficial. En cierto sentido, en la coyuntura de 1934 la Inquisición se convertía en un símbolo nacional, ya sea para repudiarlo o para celebrarlo. EI tópico inquisitorial, típico de la llamada «Leyenda negra», se reforzaba en aquella España en ebullición. En el marco del centenario de la supresión definitiva del tribunal, los sectores republicanos «radicales» y la izquierda intentaban disociar la identidad nacional del catolicismo, mientras que el extremo integrista reivindicaba la catolicidad de la nación rechazando la escisión entre política y religión. La memoria sobre la Inquisición se asociaba, pues, a distintas formas de pensar la identidad nacional y la convivencia política.

El legado del Santo Oficio aparecía como un tema de actualidad. La coyuntura internacional, signada por el nazismo y el fascismo, no era ajena a la elaboración de aquellas memorias. Por una parte, la prensa republicana opositora y de izquierda manifestaba el temor de que la Inquisición renaciera «bajo la forma de dictadura fascista-clerical». Por otra parte, la prensa monárquica confesional reivindicaba a la Inquisición como la creadora de la conciencia nacional al tiempo que elogiaba la vigilancia inquisitorial como concepción totalitaria del poder. Se denunciaba, además, la celebración como parte de un «truco histórico» pues se reivindicaba que, en lugar del centenario de la definitiva supresión de la Inquisición, debía conmemorarse los cien años de los actos de violencia anticlerical. Se acusaba, por cierto irónicamente, a los republicanos-socialistas de engendrar «un Santo Oficio laico» en su represión de la disidencia política. Desde las posturas más moderadas y reflexiones más pausadas, el legado de la Inquisición parecía asociarse tanto a la violencia revolucionaria como a la concepción totalitaria del poder. ${ }^{89}$ El fanatismo que aspira a gobernar las creencias,

89 Sobre una perspectiva historiográfica en ese sentido, véase: Versluis 2006. sean religiosas o políticas, era así denunciado. En efecto, el proyecto de transformación laica podía entrañar también una actitud intransigente.

A su vez, como señaló López Vela $(1999,220)$, «publicismo e historiografía han mantenido una estrecha relación en el tratamiento del Santo Oficio». De hecho, en un contexto atravesado por las memorias cruzadas sobre la Inquisición, la prensa confesional monárquica expresaba la necesidad de desarrollar estudios históricos sobre el tribunal desplegándose allí la formulación de una propuesta católica de investigación. De modo que el significado de la Inquisición española demostró ser objeto de disputa tanto del campo de la historiografía como de la memoria sobre el tribunal desplegada en la arena de la opinión pública en ocasión del centenario de su abolición.

Sucede que aquellas memorias no solo relataban una historia, sino que, a la vez, contribuían a crear otras. El Santo Oficio se constituyó así en un símbolo para pensar la política y la religión en la España contemporánea. La pregunta por la identidad nacional seguiría ensayando respuestas a través de las creencias. Disputadas entre la historia y la memoria, aquellas representaciones sobre la Inquisición española nos recuerdan que los conflictos políticos-religiosos tienen, como advierte Walzer (2010, 242), un final abierto.

\section{BiBLIOGRAFÍA}

Abellán, José Luis. 1984. "La persistencia de la "mentalidad inquisitorial" en la vida y la cultura española contemporánea y la teoría de las "dos Españas"». En Inquisición española y mentalidad inquisitorial, Ponencias del Simposio Internacional sobre Inquisición Nueva York, abril de 1983, edición de Ángel Alcalá y otros, 542-555. Barcelona: Ariel.

Alonso García, Gregorio. 2014. La nación en capilla. Ciudadanía católica y cuestión religiosa en España (1793-1874). Granada: Editorial Comares.

Álvarez Junco, José y Gregorio De la Fuente. 2017. El relato nacional. Historia de la historia de España. Madrid: Taurus.

Álvarez Rey, Leandro. 2000. «La forja de un republicano: Diego Martínez Barrio (1833-1962)». Ayer. Revista de Historia contemporánea 39: 181-206.

Álvarez Tardío, Manuel. 2002. Anticlericalismo y libertad religiosa. Política y religión en la Segunda República Española. Madrid: CEPC.

Avilés Fernández, Miguel. 1989. «La literatura inquisitorial (Aportaciones a la historia de un género historiográfico)». Revista de la Facultad de Geografía e Historia 4: 79-114.

Bethencourt, Francisco. 1997. La Inquisición en la época moderna, España, Portugal, Italia, siglos XV-XIX. Madrid: Akal.

Campos Pérez, Lara. 2016. Celebrar la nación. Conmemoraciones oficiales y festejos durante la Segunda República. Madrid: Marcial Pons.

Casado, María Ángeles y Emilio La Parra López. 2013. La Inquisición en España. Agonía y abolición. Madrid: Akal.

Champion, Justin A. 2000. "To govern is to make subjects believe": Anticlericalism, politics and power, c. 1680-1717». En Anticlericalism in Britain, c. 1500-1914, ed. Nigel Aston y Matthew Cragoe, 42-67. Stroud: Sutton Pub.

Checa Godoy, Antonio. 1989. Prensa y partidos políticos durante la II República. Salamanca: Universidad de Salamanca.

Claramunt, Salvador, Luis Adão da Fonseca, Pere Molas Ribalta, Adolfo Carrasco Martínez y Antonio Morales Moya. 2001. Las conmemoraciones en la historia. Valladolid: Universidad de Valladolid.

Contreras, Jaime y Jean-Pierre Dedieu. 1980. «Geografía de la Inquisición española: la formación de los distritos (1470-1820)». Hispania: Revista Española de Historia 40 (144): 37-94. 
Cuenca Toribio, Manuel. 2006. «Vestigios de la Inquisición: tolerancia e intolerancia en las Constituyentes de 1855». En Intolerancia e Inquisición: Actas del Congreso Internacional de Intolerancia e Inquisición celebrado en Madrid y Segovia en febrero de 2004, coordinación de José Antonio Escudero López, tomo 3, 559-583. Madrid: Sociedad Estatal de Conmemoraciones Culturales.

Cueva Merino, Julio de la. 2014. «El laicismo republicano: tolerancia e intolerancia religiosa en la Segunda República española». Mélanges de la Casa de Velázquez 44 (1): 89-109. https://doi. org/10.4000/mcv.5515

Di Stefano, Roberto. 2000. «De la cristiandad colonial a la Iglesia nacional. Perspectivas de investigación en historia religiosa de los siglos XVIII y XIX». Revista Andes 11: 83-113.

Elorza, Antonio. 1989. El temido árbol de la libertad. España y la Revolución Francesa. Barcelona: Aymes.

Foucault, Michel. 2016. Seguridad, territorio, población: curso en el Collége de France (1977-1978). México: Fondo de Cultura Económica.

Fuentes, Juan Francisco. 1990. «Datos para una historia de la policía política en la década ominosa». Trienio, Ilustración y Liberalismo. Revista de Historia 15: 97-124.

García Cárcel, Ricardo. 1992. La leyenda negra. Historia y opinión. Madrid: Alianza Editorial.

García Cárcel, Ricardo. 1996. «Veinte años de la historiografía sobre la Inquisición». Publicaciones de la Real Sociedad Económica de Amigos del País: 231-254.

García Cárcel, Ricardo. 2011. La herencia del pasado: las memorias históricas de España. Barcelona: Galaxia Gutenberg - Círculo de Lectores.

Gil Pecharromán, Julio. 2000. Sobre España inmortal, sólo Dios, José María Albiñana y el Partido Nacionalista Español (1930-1937). Madrid: UNED.

Gillis, John R., ed. 1994. Commemorations. The politics of national identity. Princeton: Princeton University Press.

Gorelik, Adrián, ed. 2004. «Dossier: El comparatismo como problema». Prismas: Revista de Historia Intelectual 8: 121-228.

Gutiérrez Molina, José Luis. 2015. «El crimen y los procesos de los Sucesos de Casas Viejas. Los campesinos y la insidia política». Cahiers de Civilisation Espagnole Contemporaine 2. https://doi. org/10.4000/ccec.5527

Haliczer, Stephen. 1984. "La Inquisición como mito y como historia: Su abolición y el desarrollo de la ideología política española». En Inquisición española y mentalidad inquisitorial, Ponencias del Simposio Internacional sobre Inquisición Nueva York, abril de 1983, edición de Ángel Alcalá y otros, 496-517. Barcelona: Ariel.

Jiménez Torres, David. 2015. «Las múltiples caras de un intelectual: Ramiro de Maeztu ante la Gran Guerra». Historia y Política 33: 49-74.

Juderías, Julián. 1917. La leyenda negra: estudios del concepto de España en el extranjero. Barcelona: Ed. Araluce.

Julliot, Caroline. 2010. Le Grand Inquisiteur, naissance d'une figure mythique au XIX ${ }^{\circ}$ siécle. París: Honoré Champion Éditeur.

Kamen, Henry. 1985. La Inquisición española. México D.F.: Grijalbo.

La Parra López, Emilio. 2001. «La transformación del anticlericalismo español: consideraciones desde el final de dos siglos». En Les fin de siécles en Espagne, dirección de Jean-René Aymes, y Serge Salün, 109-123. Paris: Presses Sorbonne Nouvelle.

La Parra López, Emilio. 2017. «Ni restaurada, ni abolida. Los últimos años de la Inquisición española (1823-1834)». Ayer. Revista de Historia Contemporánea 4 (108): 153-175.

Lefort, Claude. 1986. Essais sur le politique XIX-XX siècles. Paris: Seuil.

López Vela, Roberto. 1990. «Inquisición y Estado. Los fundamentos historiográficos de una interpretación política (1930-1990)». Chronica Nova 18: 267-342.

López Vela, Roberto. 1994. «La jurisdicción inquisitorial y eclesiástica en la historiografía». Espacio, Tiempo y Forma, Serie IV, Historia Moderna 7: 383-408.

López Vela, Roberto. 1996. «Integrismo y Menéndezpelayismo en la historiografía de la Restauración. Cappa y la Historia de la Inquisición». En Política, Religión e Inquisición en la España Moderna, coordinación de Pablo Fernández Albaladejo, José Martínez Millán y Virgilio Pinto Crespo, 408-444. Madrid: Universidad Autónoma de Madrid.

López Vela, Roberto. 1999. «Inquisición y España: Ios géneros y los ritmos de un debate esencialista en los siglos XIX y XX». En Inquisición y Sociedad, coordinación de Ángel de Prado Moura, 219-260. Valladolid: Universidad de Valladolid.

López Vela, Roberto. 2000. "Historiografía inquisitorial, catolicismo y España. Análisis de una trayectoria historiográfica». En Historia de la Inquisición en España y América, dirección de Joaquín Pérez Villanueva y Bartolomé Escandell Bonet, tomo III, 83-168. Madrid: Biblioteca de Autores Cristianos.

López Villaverde, Ángel Luis. 2018. «Iglesia y República: ¿conflicto o persecución religiosa?». En Las dos Repúblicas en España, coord. Ana Martínez Rus y Raquel Sánchez García, 303-327. Madrid: Editorial Pablo Iglesias.

Manent, Pierre. 1993. «Christianisme et démocratie: Quelques remarques sur l'histoire politique de la religion, ou, sur l'histoire religieuse de la politique moderne». En L'Individu, le Citoyen, le Croyant, coordinación de Pierre Manent, Pierre Collin, Pierre Maraval, Michael Lowy, Jean-Marc Ferry y Jacques Rollet, 53-73. Bruselas: Publications des Facultés Universitaires Saint-Louis.

Manent, Pierre. 2001. «Le vecteur théologico-politique». En Cours Familier de Philosophie Politique, 39-54. Paris: Fayard.

Martínez Millán, José. 2007. La Inquisición española. Madrid: Alianza Editorial.

Menéndez y Pelayo, Marcelino. (1880-1882). 1956. Historia de los heterodoxos españoles. Madrid: Biblioteca de Autores Cristianos.

Montero, Feliciano, Antonio C. Moreno y Marisa Tezanos. 2014. Otra Iglesia. Clero disidente durante la Segunda República y la Guerra Civil. Gijón: Trea.

Moreno, Doris. 2004. La invención de la Inquisición. Madrid: Fundación Carolina - Centro de Estudios Hispánicos e Iberoamericanos.

Moreno Luzón, Javier. 2003. «Memoria de la nación liberal: el primer centenario de las Cortes de Cádiz». Ayer. Revista de Historia Contemporánea 52: 207-235.

Nora, Pierre. 1984-1992, ed. Les lieux de mémoire. 3 vols. París: Gallimard.

Pérez, Joseph. 2005. La Inquisición española. Crónica negra del Santo Oficio. Madrid: Martínez Roca.

Torres Puga, Gabriel. 2004. Los últimos años de la Inquisición en Nueva España. México D.F.: Consejo Nacional para la Cultura y las Artes.

Torres Puga, Gabriel, ed. 2017. «Dossier. El final de la Inquisición en el mundo hispánico: paralelismos, discrepancias y convergencias». Ayer. Revista de Historia Contemporánea 4, 108.

Townson, Nigel. 2009. «¿Vendidos al clericalismo? La política religiosa de los radicales en el segundo bienio, 1933-1935». En Laicismo y catolicismo. El conflicto político religioso en la Segunda República, edición de Julio de la Cueva Merino y Feliciano Montero, 73-90. Alcalá de Henares: Universidad de Alcalá.

Ramos, Dolores. 2002. «Federalismo, laicismo, obrerismo, feminismo: cuatro claves para interpretar la biografía de Belén Sárraga». En Discursos, realidades y utopías: la construcción del sujeto femenino en los siglos XIX y XX, coordinación de Dolores Ramos Palomo y María Teresa Vera Balanza, 125-164. Barcelona: Anthropos.

Robinson, Richard. 1974. "La República y los partidos de la derecha». En Estudios sobre la República y la Guerra Civil Española, coordinación de Raymond Carr, 67-105. Barcelona: Ariel.

Ruiz Torres, Pedro. 2001. «Les usages politiques de l'histoire en Espagne. Formes, limites et contradictions». En Les usages politique du passé, edición de François Hartog y Jacques Revel, 129-156. Paris: EHESS.

Salomón Chéliz, María del Pilar. 2002. «El discurso anticlerical en la construcción de una identidad nacional española republicana». Hispania Sacra 54: 485-497. https://doi.org/10.3989/hs.2002.v54. i110.179

Sempere Muñoz, Daniel. 2008. La Inquisición española como tema literario. Política, historia y ficción en la crisis del Antiguo Régimen. Londres: Tamesis Books.

Suárez Cortina, Manuel. 2014. Entre cirios y garrotes: política y religión en la España contemporánea, 1808-1936. Santander - Cuenca: Edi- 
torial de la Universidad de Cantabria - Ediciones de la Universidad de Castilla-La Mancha.

Tcherbbis Testa, Jimena. 2019. «Imaginar un nuevo orden político: la crítica liberal a la Inquisición española en la prensa de Lima y Buenos Aires durante las Cortes de Cádiz (1810-1814)». Boletín del Instituto de Historia Argentina y Americana "Dr. Emilio Ravignani» 50: 52-97.
Tuñón de Lara, Manuel. 1977. «La política eclesiástica durante la II República española». Fomento Social 27: 261-278.

Versluis, Arthur. 2006. The New Inquisitions. Heretic- Hunting and the Intellectual Origins of Modern Totalitarianism. Oxford: Oxford University Press.

Walzer, Michael. 2010. Pensar políticamente. Barcelona: Paidós. 